\title{
Amos Funkenstein on the Theological Origins of Historicism
}

Samuel Moyn

When I look at this age with the eye of a distant future, I find nothing so remarkable in the man of the present day as his peculiar virtue and sickness called "the historical sense."

-Friedrich Nietzsche

The meaning of history (as a whole) and the meaning in history (of its facts) underwent a revolution of no less significance than the revolution in the natural sciences. Again we wonder: how radical was this break, what precisely was new in this "New Science"?

-Amos Funkenstein

\section{Introduction}

It is not, of course, a new suggestion to turn history on itself in order to discover the historical conditions for the possibility of the modern historical outlook. This project began in the early modern period, taking on a new direction and momentum with J. C. Gatterer's complaint that his discipline had studiously exempted itself from the methods it pioneered. ${ }^{1}$ Few recent contributors to this ongoing endeavor, perhaps, have undertaken as interesting or fundamental a version of it as the late Amos Funkenstein. As his student Abraham

Thanks to Ann Blair, for whose Harvard University seminar on early modern approaches to history I originally wrote this paper up, and to Leora Batnitzky, Julian Bourg, Peter Eli Gordon, Martin Jay, Abraham Socher, and a JHI reviewer for valuable advice.

1 "I do not know why this branch of learning has suffered the unfortunate fate of not having admirers and practitioners who up to now ever thought of producing a HisTORY OF HisTORY worth reading." See Herbert Butterfield, Man on His Past: The Study of the History of Historical Scholarship (Cambridge, 1955; repr., Boston, 1960), 5; and Peter Hanns Reill, The Enlightenment and the Rise of Historicism (Berkeley, 1975). 
P. Socher has recently observed, “One of Amos Funkenstein's central historical concerns was the development of the discipline and methods of history itself." Nonetheless, Funkenstein's contribution in this realm of inquiry remains littleknown and ill-understood; this paper attempts a critical overview of it.

Born in Palestine in 1937, Funkenstein died prematurely in 1995 after teaching for more than two decades mainly at several Californian universities. Educated in postwar Germany, Funkenstein received his doctorate from the Free University of Berlin in 1964 under the guidance of such teachers as Wilhelm Berges, Reinhard Elze, Dieter Henrich, Adolf Leschnitzer, and Jacob Taubes. After the publication of his dissertation, Heilsplan und natürliche Entwicklung: Formen der Gegenwartsbestimmung im Geschichtsdenken des hohen Mittelalters (Munich, 1965), Funkenstein restricted himself mainly to the article form until the publication of his landmark Christian Gauss lectures at Princeton University as Theology and the Scientific Imagination from the Middle Ages to the Seventeenth Century (Princeton, 1986); in Jewish history, Perceptions of Jewish History (Berkeley, 1993) collected his major articles to complement his short volume on Maimonides: Nature, History, and Messianic Beliefs (Tel Aviv, 1998), a posthumous translation by Shmuel Himelstein of a Hebrew work of 1983.

Funkenstein, a confirmed adherent of the German style of Geistesgeschichte, began his career with a dissertation dedicated, in part, to friendly criticism of Karl Löwith's Meaning in History, a study of the biblical, patristic, and medieval lineage of the modern philosophy of history. And whatever the corrections he offered to Löwith and the prior German discussion of the derivation of Western historical thought Funkenstein never left behind many of the basic assumptions of the discourse into which he initially entered. ${ }^{3}$ It is essential to understand Funkenstein's project as germinating in a particular place at a particular time, postwar Germany. Nevertheless, contextualization may not exhaust the interest of his argument, in part because Funkenstein offered a genealogy of the contextualizing spirit itself. The predominant focus in what follows is, therefore, on the possible lessons and not on the obvious limitations of Funkenstein's account, idealistic, disembodied, and geistesgeschicht-lich though it always remained. In what follows I do not try to verify historically (much less advocate) the account Funkenstein generated; I aim only to reconstruct it and to reflect on what it might add to more familiar and ingrained ways of thinking about the historical backgrounds to history.

\footnotetext{
${ }^{2}$ Abraham P. Socher, "Of Divine Cunning and Prolonged Madness: Amos Funkenstein on Maimonides' Historical Reasoning," Jewish Social Studies, n.s., 6 (1999), 7.

${ }^{3}$ Karl Löwith, Meaning in History: The Theological Implications of the Philosophy of History (Chicago, 1949). This study originally appeared in English, then in German as Weltgeschichte und Heilsgeschehen: Die theologischen Voraussetzungen der Geschichts-philosophie, tr. Hanno Kesting (Stuttgart, 1953). A set of very similar themes followed through time is to be found in Frank E. Manuel, Shapes of Philosophical History (Stanford, 1965).
} 
In his dissertation Funkenstein cited as a methodological guide G. W. F. Hegel's dictum from the "Introduction" to his Lectures on the Philosophy of History that "[i]n our language the term History unites the objective with the subjective side, and denotes the res gestae quite as much the historia rerum gestarum; in other words, it comprehends not less what has happened, than the narration of what has happened." The term "history" in English as well as in Hegel's German has two different referents. One is the "objective" res gestae, the historical events themselves. The other is the "subjective" historia rerum gestarum, their narrative representation. "This union of the two meanings," Hegel had gone on to note of the coincidence of two distinct acceptations in the same word, "has to be regarded as of a higher order than mere outward accident"; for "[i]t is an internal vital principle common to both that produces them simultaneously."

Out of allegiance to Hegel's argument Funkenstein made the processes of historical evolution of both the objective and subjective sides of modern historical consciousness central subjects of his work. Hegel's observation, Funkenstein seems to have assumed, suggested that the "objective and subjective side" of history have to be considered and therefore chronicled together because their fates had always been linked. But Funkenstein could not follow up Hegel's insight without in a sense reinventing it. For Hegel apparently relied for his conclusion on the strange principle that all events worthy of the name are recorded - both depend on the rise of the state - so that "history" as event and "history" as report are necessarily congruent. If the subjective and objective dimensions of history were to maintain the symbiotic relationship Hegel attributed to them, then, Funkenstein would have to find a new explanation of their interdependence. ${ }^{6}$

Hegel's observation about the duality of "history" is repeated and brought to a higher level today in a duality at the heart of the newer word "historicism." It is useful to think of Funkenstein's project as an attempt to show that the two contemporary meanings of "historicism," one objective and one subjective, are unified just as significantly — that is, non-coincidentally—as Hegel originally claimed for the two meanings of "history."

On the objective side, that of the res gestae, Funkenstein chronicled the rise of the definition of historicism that, to avoid confusion, is in the Anglo-

${ }^{4}$ G. W. F. Hegel, The Philosophy of History, tr. J. Sibree (New York, 1944), § 68.

${ }^{5} \mathrm{Ibid}$., translation altered.

${ }^{6}$ As Funkenstein explained early and late, the doctrine that events do not "count" unless recorded - with the consequence that history only begins with the state-is considerably older than Hegel's philosophy. See Heilsplan, 76 and Perceptions, 3-4. Such views explain the otherwise unintelligible word and concept of "prehistory." 
American world sometimes called "the philosophy of history." This version of historicism involves a thesis about how the historical process is structured and organized. It is the definition of the term given by Karl R. Popper in various treatments and, climactically, in his book-length indictment of The Poverty of Historicism. ${ }^{7}$ Popper's notorious attack on Karl Marx and his communistic votaries targeted their peculiar notion that history follows a foreordained script or compulsive sequence - one given in advance and followed by actors even when they are unaware of their participation in it. But what are the origins of this conception of how the historical process is organized? Funkenstein made this question one focal point of his investigations.

On the subjective side, that of the historia rerum gestarum, Funkenstein singled out for explanation the other, more canonical definition of historicism, the one that describes not the substantive organization of the historical process but rather the methodological principle of the historian's craft. This principle holds that epochs differ fundamentally from one another and have to be understood in their own terms. Each age is "equally immediate to God," as Leopold von Ranke expressed it in a famous apothegm. This conception is sometimes thought to have a substantive component, presuming the "individuality" of each historical moment or epoch. But it has a methodological thrust, for it suggests that the only understanding of a historical datum - text or event - is a contextual one, anchored in the difference and particularity of a singular time. But what are the origins of this methodological conception of how the past is to be understood by the historian? ${ }^{8}$ Funkenstein made this question a second focal point of his work.

It has been observed by many writers that the rivalry between the definitions of historicism is so dangerous because they refer not merely to different but to opposite conceptions. Where the one definition fastens on the particularity of every historical moment and separates it from all the rest, the alternative definition binds each historical moment to every other so that they combine to add up to a complete master-script of time. Where the one separates every moment from the entire historical process, the other subsumes each within it. So defined, it seems hard to advocate both consistently. But following Hegel,

${ }^{7}$ Karl R. Popper, The Poverty of Historicism (Boston, 1957).

${ }^{8}$ On the term, see Dwight N. Lee and Robert N. Beck, "The Meaning of 'Historicism,'” American Historical Review, 59 (1953-54), 568-77; and Georg G. Iggers, "Historicism: The History and Meaning of the Term," JHI, 56 (1995), 129-52. The most capacious attempt to historicize the rise of the new methodological consciousness is Friedrich Meinecke, Die Entstehung des Historismus (2 vols., Munich, 1936), which appeared in English as Historism: The Rise of a New Historical Outlook, tr. J. E. Anderson (New York, 1972). The major discussions of historicism as philosophical, theological, and cultural quandary took place in early twentieth-century Germany in the context of what Ernst Troeltsch labeled the "crisis" of historicism. See Troeltsch, "Die Krisis des Historismus," Die Neue Rundschau, 33 (1922), 572-90 and Annette Wittkau, Historismus: zur Geschichte des Begriffs und des Problems (Göttingen, 1992). 
whose philosophy had perhaps gone furthest in combining both conceptions, ${ }^{9}$ Funkenstein tried to explain why these apparent opposites shared more than just their name.

It is true, of course, that other scholars, preeminently Karl Löwith, had attempted to historicize the philosophy of history before. The central novelty of Funkenstein's effort, I believe, is to have done so without leaving out the rise of the other kind of historicism which likewise made Hegel's approach so powerful. The key to the relationship between the two kinds of historicism, the one objective and the other subjective, lay in the fact that they emerged togetheror so, at least, Funkenstein argued. They became bitter rivals only late in the day, but in their origins they were inseparable.

\section{Historicism as Teleology}

The first kind of historicism, involving the attribution of a singular ruling meaning and purpose to time, is considerably older than the other one-indeed, if Funkenstein is correct, it made the other possible. The teleological philosophy of history Funkenstein traced back to the very foundational periods of Western monotheism and, more specifically, to the Hebrew prophets. It is with this ancient material that Funkenstein began his dissertation, Heilsplan und natürliche Entwicklung, very early establishing to his satisfaction the fundamentals of a story to which he constantly returned.

In his dissertation Funkenstein joined the general drift of this literature in tracing what Erich Auerbach called the biblical discovery of "the concept of the historically becoming." 10 The Hebrew Bible as a whole depends on novel conceptions of historical time insofar as the Israelites understood themselves as a youthful and novel sect. But it is - so Funkenstein argued - thanks to the later prophets of the subjugated people that the historical sense is truly born. In the admonitions and promises of Hebrew apocalyptical figures, one could find a kind of detailed temporal imagination, to be taken up into early Christianity, that made possible the very notion of history as the purposive unfolding of time towards an end state. For they claimed that the end of time itself is already appointed and in the process of coming to pass according to a carefully ordained schedule. All history is future history. "The fascination with historical time and its structure," Funkenstein wrote, counted as the

${ }^{9}$ See Frederick C. Beiser, "Hegel's Historicism," in Beiser (ed.), The Cambridge Companion to Hegel (Cambridge, 1993), and esp. Michael N. Forster, Hegel's Idea of a "Phenomenology of Spirit" (Chicago, 1998), Part III.

${ }^{10}$ Erich Auerbach, Mimesis: Dargestellte Wirklichkeit in der abendländische Literatur (Berlin, 1946), in English, Mimesis: The Representation of Reality in Western Literature, tr. Willard R. Trask (Princeton, 1953), 23. 
important contribution of the apocalyptic mentality to the Western sense of history. The apocalyptician grasped all of history as a structured, well-articulated meaningful unity. [He gave a] detailed account of the future drama of the end, down to days, hours, and precise actors, [based on] his perception of the whole of history as a dramatic struggle between the forces of good and evil. ${ }^{11}$

In this frame of thought the "very powerlessness of Israel" looked paradoxically to be

proof of God's immense power, which manifests itself by his using the biggest empires, Assyria, Babylon and Egypt, as "the rod of his wrath" ... to chastise Israel and to purify it. Yet these world-powers are unaware of it, of their historical mission..., and attribute their success to their very own strength and their God's. Here, perhaps, we encounter the earliest, original version of reading into the history "the cunning of God" or "the cunning reason," ... [since] by following their own, blind urge for power, the nations of the world unknowingly serve a higher design. ${ }^{12}$

Already, Funkenstein seemed to imply, Hegel is on the horizon. As Yosef Yerushalmi later expressed the same point, "If Herodotus was the father of history, the fathers of meaning in history were the Jews." 13

In beginning with this material in his dissertation Funkenstein appears to have taken Löwith's Meaning in History as his point of departure. A citation to the German edition of Löwith's book appears in the very first footnote of Funkenstein's career of many footnotes. ${ }^{14}$ Though written in exile before Löwith had returned to the University of Heidelberg from America to take up his commanding position in the postwar German academy, The Meaning of History is, like Funkenstein's later work, anomalous only where it appeared in print and not in the geographical and academic culture in which it originated in spirit. The comparative strength of theology in the German universities had led to a veritable obsession, from the later Wilhelmine to the postwar periods, with the relation between "Christianity and culture." The immediate post-World War II moment saw a spate of works about the theological origins of historical reason. ${ }^{15}$ Funkenstein's teacher, Jacob Taubes, established a trend when he pub-

${ }^{11}$ Funkenstein, Perceptions, 77.

${ }^{12}$ Ibid., 54 (note omitted); cf. 72-73 and Theology, 243-50.

${ }^{13}$ Yosef Hayim Yerushalmi, Zakhor: Jewish History and Jewish Memory (Seattle, 1982), 8.

${ }^{14}$ See Funkenstein, Heilsplan und natürliche Entwicklung, 123, n. 1.

${ }^{15}$ See Oscar Cullmann, Christ and Time: The Primitive Christian Conception of Time and History, tr. Floyd V. Filson (Philadelphia, 1950); Karl Jaspers, The Origin and Goal of History, tr. Marcus Bullock (New Haven, 1953); and Eric Voegelin, The New Science of Politics: An 
lished his Western Eschatology, an idiosyncratic account of the development of the philosophy of history written in a vatic style, covering similar material from the ancient Israelites to Karl Marx and suggesting the impossibility of understanding the historicity of particular events without grasping the deeper and more profound "possibility of history." In a book that matched Löwith's in range and theme, Taubes posed a question that Funkenstein in a far more nuanced, careful, and historical mode preserved and transmitted to American readers unaware - perhaps to their benefit - that history is a problem. ${ }^{16}$ German conservatives, in these years, wrote of living in a "posthistorical" epoch, and in a Cold War world they dismissed Communism as the transparent but perverted secularization of a theological, chiliastic design that remained delusionally anchored in the myth of progress and redemption in history. ${ }^{17}$ Löwith's book argued the need to retreat from the modern historical consciousness that Friedrich Nietzsche had tried and failed to master, on the grounds that "there has never been and never will be an immanent solution of the problem of history, for man's historical experience is one of steady failure."18

Funkenstein's most important claim to originality in relation to this older German (as well as to contemporary Anglo-American) discussion is to have studied historicism as a teleology without neglecting historicism as methodology, a move essentially without precedent in Löwith, Taubes, and others. Still, Funkenstein clearly hoped to affiliate with (and criticize from within) the project of finding the theological origins of teleological modes of thought that Löwith had made so compelling. Consequently, Funkenstein's dissertation, which ends with medieval historians, is chiefly devoted to their theological sources, beginning with biblical prophecy.

Introduction (Chicago, 1952), esp. chap. 4.; also Hans Urs von Balthasar, A Theology of History (New York, 1950); and Josef Pieper, The End of Time: A Meditation on the Philosophy of History, tr. Bullock (New York, 1954). See Carl Schmitt's review of Löwith's book, "Drei Stufen historischer Sinngebung," Universitas, 5 (1950), 927-31, and Leo Strauss, Natural Right and History (Chicago, 1953), 25.

${ }^{16}$ Jakob Taubes, Abendländische Eschatologie (Berne, 1947; rpt. Munich, 1991), on which see Reinhard Mehring, "Karl Löwith, Carl Schmitt, Jacob Taubes, und das 'Ende der Geschichte,'” Zeitschrift für Religions- und Geistesgeschichte, 48 (1996), 231-48; and Richard Faber, Eveline Goodman-Thau, and Thomas Macho (eds.), Abendländische Eschatologie: Ad Jacob Taubes (Würzburg, 2001).

${ }^{17}$ See Lutz Niethammer, Posthistoire: Is History at an End?, tr. Patrick Camiller (London, 1992).

${ }^{18}$ Löwith, Meaning in History, 191. See Jürgen Habermas, "Karl Löwith: Stoic Retreat from Historical Consciousness," in Philosophical-Political Profiles, tr. Frederick G. Lawrence (Cambridge, Mass., 1983), Jeffrey Andrew Barash, "The Sense of History: On the Political Implications of Karl Löwith's Interpretation of Secularization," History and Theory, 37 (1998), 6982, and Richard Wolin, Heidegger's Children: Hannah Arendt, Karl Löwith, Hans Jonas, and Herbert Marcuse (Princeton, 2001), chap. 4. 
Since Funkenstein never left this idealist historiography behind, restricting himself to criticizing it from within, his own beginnings are fundamental to understanding not only his contribution but also its potential limits. His dissertation, which focuses more than his later writings on the early parts of the evolution of Western historical consciousness, could nevertheless claim several advances on Löwith's work. In the first place it is more detailed. Fun-kenstein's early study shared the same ultimate horizon in the nineteenth-century philosophy of history. But where Löwith had simply examined the high points of the trajectory, leaping from the Bible to Augustine and his student Orosius and from there to Joachim of Fiore before an unceremonious entry into the early modern period, Funkenstein's doctoral work dwelled at greater length and with greater discernment on the early stages of the development of the notion of reason in history, before Joachim's transformative intervention, leaving the pursuit of the story into the early modern and modern periods for later works.

But Funkenstein's dissertation made another, substantive advance on Löwith's work. In the preparatory section of his dissertation concerning the "ancient foundations" Funkenstein claimed the major innovation of distinguishing sharply between what he called "apocalyptics" and "eschatology." Löwith, Funkenstein suggested, had missed this critical difference. Where apocalyptics had insisted on the imminence of the parousia, eschatology had to suppress the apocalyptic impulse in order to postpone the end of history indefinitely into the future. The reason for this maneuver is that failures of predictions of the First (for the Jews) or Second Coming (for the Christians) had to be converted from a source of embarrassment into a result intended from the outset. The central argument Funkenstein made is thus that the two approaches to history were not truly continuous. Instead, eschatology had to be invented through the departure from apocalyptics, so that the "revolutionary" consciousness had to become "evolutionary." The implication of this argument - one made with striking simultaneity by the philosopher Hans Blumenberg in his defense of the modern age - is that the eschatology secularized in the early modern period had itself originally been an agent of secularization: a means of accommodating religions of impatient expectation to a world that disappointingly refused to end. Not apocalyptics but eschatology made the maturation of Western historical reasoning possible. ${ }^{19}$

After the establishment of this point much of the rest of Funkenstein's dissertation is dedicated to medieval theology and historiography - chiefly in the eleventh and twelfth centuries - and the sense in which it both resumed and

${ }^{19}$ In his book, Blumenberg made the claim that Christianity had already been "secularized" well before modern times and therefore could not claim any special purity from secularization. See Hans Blumenberg, Die Legitimität der Neuzeit (Frankfurt, 1966), 32-39. This work appeared later in English as The Legitimacy of the Modern Age, tr. Robert M. Wallace (Cambridge, Mass., 1983). 
detailed the initial eschatological scripts left over especially from the patristic authors. It would take too long to summarize the many facets Funkenstein claimed to unveil and it is in any case unnecessary for my purposes. ${ }^{20}$ Various writers came to see history not only as evolutionary but also gradualistic as well as progressive. The slow maturation of the world in the "middle" ages came to be likened to the natural life of a biological person in which the present is always somewhere in between beginning and ending. The appearance of misdirection or decline in history various philosophers explained away as the mysterious workings of providence, intentional in God's mind even when they surpassed the merely human understanding. The conclusion of central importance for this paper is that the Middle Ages had, so Funkenstein argued, a mature sense of the operations of God in the historical process - what Maimonides called, in a phrase that Funkenstein saw as a clear if distant anticipation of Hegel, "God's cunning." 21

Each chapter of Funkenstein's magnum opus Theology and the Scientific Imagination is devoted to the early modern secularization of a divine attribute. In his treatment of the origins of the modern historical attitude from God's providence Funkenstein returned to finish the story he began in his dissertation on the origins of the teleological interpretation of the sweep of time. The story culminated in Vico's conception of providence, which fully internalized (for the gentiles at least) God's intention to the orderly unfolding of the historical process, making it the outcome if not of man's intention then at least of man's creative activity. "Thus," Funkenstein concluded,

"providence" came to signify man's emancipation from nature or even from God, the spontaneity of his social endeavors... With the help of this version of a List der Vernunft, Vico can reintroduce providence into history and thus resume, on a richer base, a tradition of Christian philosophy of history ... seeking to establish the correspondence between the divine plan of salvation and the immanent nature of man.

But Vico also made the figure of thought available for those who would cast historical evolution as a wholly human activity, even if it is to be fully understood only from the end of the process, when the philosopher can let fly the Owl of Minerva at dusk. ${ }^{22}$

${ }^{20}$ See Funkenstein, Heilsplan, Parts II and III and Theology, 243-75.

${ }^{21}$ See Funkenstein, Heilsplan, 169 n. 17, Theology, chap. 4, esp. 232; Perceptions, 131-55; Maimonides, §§ 3-10. A crucial point of inspiration for much of Funkenstein's project may well have been the attempt by his teacher to find anticipations of Hegel in another medieval thinker. See Funkenstein, Theology, 236, n. 52, and Wilhelm Berges, "Anselm von Haverberg in der Geistesgeschichte des 12. Jahrhunderts," Jahrbuch für Geschichte Mittel und Ostdeutsch-landsm, 5 (1956), 52.

${ }^{22}$ Funkenstein, Theology, 288. Cf. António Pérez-Ramos, "And Justify the Ways of God to Men," Studies in History and Philosophy of Science 21 (1990), 323-39. It has proved difficult for 


\section{Historicism as Methodology}

Funkenstein's main achievement, however, is not to have intervened in the "secularization debate" about the origins of modern teleologies out of theological scripts; it is his argument that the historical method itself has to be understood, in important part, as a historical byproduct of the secularization process. ${ }^{23}$ Already Funkenstein's dissertation, in its most important difference from Löwith, Blumenberg, and other secularization theorists, is fundamentally interested in the implications of historical scripts for understanding historical practice; it turns from the theological materials in the early part of the book to concrete examples of medieval historical writing in figures such as Rodolfus Glaber, Frutolf of Michelsberg, Hugh of Fleury, and Otto of Freising. But Funkenstein refused to restrict his sense of the linkage to the medieval period. The chapter he wrote on the secularization of God's providence in Theology and the Scientific Imagination is a detailed portrait of the connection between the secularization of theology and the rise of the modern historical method.

It may not seem surprising that the philosophy of history, even when only nascent in the form of theodicy, should have compelled some awareness that different periods are characterized by distinct mentalities. But Funkenstein made this hypothesis the source of a rich historical investigation into the origins of modern historicism. For this reason he sought the origins of methodological historicism, in the sense of distinction of different ages from one another, not only in their political actors but in their more fundamental social understandings, in the theological discovery of history in general. If his hypothesis is correct, one should expect to be able to find a nascent methodological consciousness of historical difference long before the early modern period.

Funkenstein considered the dominant classical and medieval impulse to be the separation of "historical facts" from "historical context." In his words, "for ancient or medieval authors, historical facts were, so to say, atomic entities that are immediately perceivable and understandable, and hardly in need of interpretation." By contrast "[i]n the modern perception, no historical fact is in and of itself meaningful: only its context endows a historical fact with meaning and significance." ${ }^{24}$ Funkenstein claimed that a proto-historicist outlook is to be

social theory to rescue the notion that man makes his own history from the notion that he will nonetheless make it according to a providential script. See Roberto Mangabeira Unger, Politics: A Work in Constructive Social Theory (3 vols.; Cambridge, 1987), esp. I, 135-43.

${ }^{23}$ Funkenstein noted that "[e]lsewhere I tried to show that Hans Blumenberg's model does not work sufficiently well to explain what he intended to explain." Funkenstein, "Response," History \& Memory, 4 (1992), 148. He presumably referred to Theology and the Scientific Imagination, but there is no explicit polemic with Blumenberg in that book. The present article does not attempt to determine Funkenstein's place in the secularization debate.

${ }^{24}$ Funkenstein, Perceptions, 24-25; he pioneered this argument in Heilsplan, 70-77 ("Die mittelalterliche Anschauung vom historischen Faktum"); but cf. Lorraine J. Daston and Katharine 
discovered in a great number of domains, but he stressed law in both Christian and Jewish traditions as a particularly rich source. In legal reasoning, Funkenstein remarked of the Jewish discussion that one can "find clear distinctions of time and place throughout: distinctions concerning customs and their context, exact knowledge of the place and time of the messages and teachers of halakha, the estimated monetary value of coins mentioned in sources, the significance of institutions of the past." But the same observation applied to the Christian milieux, so that "[t]he degree of historical awareness of the commentators and creators of the halakha was approximately the same as the degree of historical awareness of the interpreters of Roman law in the Middle Ages prior to the development of the mos gallicus." 25 But legal texts of the period were for Funkenstein "only one of the many instances of thinking about history [for] the exegetical, homiletic, and philosophical literature abound with them."26

Instead of concentrating most assiduously on the law, however, Funkenstein furthered his thesis at greatest length in his history of the "principle of accommodation" generally and through a study of the use which the medieval philosopher Maimonides made of it specifically. Accommodation is the theological notion that because humans live in historical time, God's timeless mind is "adjusted" to suit their particular level of development. Because "the Scriptures speak the language of man," as a rabbinic formula had it, God's word had to be interpreted not literally but through transposition to the age to which evolution had brought humankind. This principle, though initially a legal tool, came to have widespread exegetical and philosophical use in both Jewish and Christian culture. ${ }^{27}$ More important, it suggested a proto-historicist outlook long before the historicist innovations of the early modern period.

Funkenstein's nearly obsessive repetition and elaboration of this argument led him again and again to Maimonides as an exemplar of the theological origins of historicism. His specific example is Maimonides's theory of the "reasons for the commandments" (ta'amei ha'mitzvot). For example, the Bible commands certain sacrifices, a practice which Jews ever since the destruction of the Temple have renounced. In light of this shift Maimonides is compelled to explain why the commandment to sacrifice is fitting only in certain historical circumstances only - why God required it not as a timeless duty but rather as a

Park, Wonders and the Order of Nature, 1150-1750 (New York, 1998), chap. 6; Peter Dear, Discipline and Experience: The Mathematical Way in the Scientific Revolution (Chicago, 1995); and Barbara J. Shapiro, A Culture of Fact: England, 1550-1720 (Ithaca, 2000).

${ }^{25}$ Funkenstein, Perceptions, 17.

${ }^{26}$ Funkenstein, "Response," 147.

${ }^{27}$ See Funkenstein, "Gesetz und Geschichte: zur historisierenden Hermeneutik bei Moses Maimonides und Thomas von Aquin," Viator, 1 (1970), 147-78; "Periodization and Self-Understanding in the Middle Ages and Early Modern Times," Medievalia et Humanistica, n.s., 5 (1974), 3-23; also Stephen D. Benin, The Footprints of God: Accommodation in Jewish and Christian Thought (Albany, 1993), originally a dissertation written under Funkenstein's supervision. 
temporary necessity. The cultic mentality of the biblical context demanded certain practices, Maimonides suggested, in an argument that (whether or not historically correct) documents an awareness of the relative integrity of each age and an ability to imagine historical evolution from one age to another. The main thrust of Funkenstein's analysis is that a theological imperative led almost necessarily to the development of a nuanced sense of the difference in collective mentalities from place to place and from age to age. While God may not evolve in history, man does. ${ }^{28}$

The consequences for historical understanding were immense. Eventually, Funkenstein claimed, the principle of accommodation matured into the methodological recognition that deep historical differences obtain between periods, with profound implications for how they are to be interpreted. This "revolution" occurred in the early modern period. As Funkenstein wrote:

Again it was Vico who first gave systematic expression to most facets of [the] methodological revolution. A new concept of historical periods as dynamical contexts emerges from his writings: it consists of the demand and of the serious attempt to determine historical periods from within, through some internal, integrating principle.... ${ }^{29}$

Thus, historicism as a methodological assumption reached maturity in the thought of the same figure who likewise appeared to complete the secularization of historicism as a substantive teleology.

In an essay published in a collection he dedicated to Funkenstein's memory, Carlo Ginzburg has recently endorsed the essence of Funkenstein's account. "The kernel of the current historiographical paradigm," he has concluded, "is a secularized version of the model of accommodation." ${ }^{30}$ As Funkenstein contended, methodological historicism developed for centuries in a theological matrix. During this time it figured as an adjunct of the other, substantive kind of historicism. Funkenstein's main contribution to the origins of the modern historical outlook is thus an argument regarding what one could term "the theological origins of historicism." In a recent publication Allan Megill has plausibly stressed "the extent to which the crisis of historicism had its roots in theology and religion, not in historiography or philosophy." The implication of Funkenstein's study is that it is, ironically, not only the crisis of historicism but

${ }^{28}$ See Funkenstein, Theology, 222-43.

${ }^{29}$ Funkenstein, Theology, 209. He claimed that Vico illuminated rather than influenced developments: "Vico's impact was negligible. But his main themes maintain a regulative role in the formation of modern historical reasoning" (ibid., 212).

${ }^{30}$ Ginzburg, Wooden Eyes: Nine Reflections on Distance, tr. Martin Ryle and Kate Soper (New York, 2001), 155. 
historicism itself that had roots in theology and religion, not in historiography or philosophy. ${ }^{31}$

\section{Early Modern Secularization}

Were Funkenstein's argument about the original interdependence of the two historicisms to become plausible, it would necessarily force a renewed appreciation of the significance of early modern historical thought. Befitting his professional specialty as a medievalist, Funkenstein argued that both the objective and subjective senses of history that appeared in Hegel's thought had their origins very deep in Western history and came to fruition in the medieval period: the main significance of the early modern era, according to his grand theory, is that they were secularized together, paving the way for Vico, Kant, and Hegel.

Funkenstein did not "leap" from medieval Jewish and Christian sources to early modern historicism. Instead, a chapter of his Theology and the Scientific Imagination is expressly dedicated to charting the path across this divide. On the objective side Funkenstein concentrated on the perception that the view of society and history as self-regulating - a view offered by a whole host of early modern thinkers, including Bernard Mandeville, Adam Smith, and Giambattista Vico, to say nothing of the later German Idealists like Immanuel Kant and Hegel himself-looked to be a secularized medieval theodicy. They retained the religious notion of history as an unfolding of God's plan, but they replaced God with reason:

The objectives of reason are realized obliquely. Without being an instrument, the historical agent acts as one by following [God's] will. Only to the subjective consciousness do subjective freedom and objective necessity appear to be in conflict. In the Zeitgeist of each phase they coincide; the growing insight into their coincidence constitutes the progress in the objective consciousness of freedom. This very mediation of freedom and necessity is "the cunning of reason." ${ }^{2}$

Like Löwith, Funkenstein went on to contend that the view of history as possessing an immanent purpose counted not as new in the early modern period but rather as very old. Only the impersonality of the intention-attributed eventually by Hegel to spirit and reason-seemed new; it somehow replaced the

${ }^{31}$ Allan Megill, "Why Was There a Crisis of Historicism?" (review of Charles R. Bambach, Heidegger, Dilthey, and the Crisis of Historicism [Ithaca, 1995]), History and Theory, 36 (1997), 419; also Thomas A. Howard, Religion and the Rise of Historicism: W.M.L. de Wette, Jacob Burckhardt, and the Theological Origins of Nineteenth-Century Historical Consciousness (Cambridge, 2000).

${ }^{32}$ Funkenstein, Theology, 204. 
originally divine intention behind the authorship of the script of history. The visible hand became invisible.

On the subjective side the early modern period saw what Funkenstein called "a revolution ... that was no less radical than the concurrent scientific revolution." This upheaval

brought about a new contextual understanding of history, in which [a] historical fact became "understood" or meaningful only through the context in which it is embedded. This applies to both historical texts and any other monument of the past. The historian must reconstruct the context, and the reconstruction is always linked to his or her "point of view" in the present. ${ }^{33}$

But the crux of Funkenstein's project is nonetheless to insist that this revolution did not occur either instantaneously or without important ancient and medieval preparation. As he remarks, Aristarchus of Samos already "formulated the basic interpretative rule that Homer should be explained by Homer alone."34 Funkenstein's purpose, however, is not only to name precursors but also to propose an argument why and how the historical revolution could have occurred. He is certainly aware of the major and standard works on the early modern transformation of the historical sensibility that prepared the notion that culture is a totality - one, as Ranke eventually held, intelligible only in its own terms. Invoking the centrality of the neo-Romanist mos gallicus, innovations in biblical research, and humanist textual study (as epitomized by Lorenzo Valla's erudition) that have received the lion's share of attention in Anglo-American scholarship of the last generation, Funkenstein allowed that "[1]egal scholarship, biblical criticism, and classical philology were the main bearers of the new historical method: history writing lagged considerably behind." 35 Still, Funkenstein considered those "bearers" of the new historical sensibility only part of the story.

This argument is perhaps the most critical implication of Funkenstein's account for students of the rise of the historical outlook because it is so foreign to the Anglo-American approach to understanding the origins of the historicist mood. It is clear that Funkenstein deeply respected, and internalized to his nar-

${ }^{33}$ Funkenstein, Perceptions, 14-15.

${ }^{34}$ Ibid., 9 n. 19; cf. 17.

${ }^{35}$ See Funkenstein, Theology, 205-13 at 212 and Perceptions, 25-27, where he cites J. G. A. Pocock, The Ancient Constitution and the Feudal Law: A Study of English Historical Thought in the Sixteenth Century (Cambridge, 1957), chap. 1; Julian H. Franklin, Jean Bodin and the Sixteenth-Century Revolution in the Methodology of Law and History (New York, 1963); and Donald R. Kelley, Foundations of Modern Historical Scholarship: Language, Law, and History in the French Renaissance (New York, 1970). Pocock's dissertation has subsequently been reprinted (Cambridge, 1987) with a long retrospect. 
rative, the work on early modern European development of historical thought inspired by J. G. A. Pocock's landmark The Ancient Constitution and the Feudal Law and continued so educationally by his followers in charting the secular, humanist, and legal origins of modern historical methodologies. Funkenstein contended, however, that it is a distortion not to place these origins of historical thought in a wider frame. Where the dominant Anglo-American view casts Renaissance humanism and its sequels as standing largely alone in making the historicism of the modern outlook possible, Funkenstein argued that it functioned at best as a catalyst in the further development of a much older and longer process. Pocock, in various writings, gave the dominant view an especially philosophical cast in his argument that only Renaissance humanism could grasp historical particularity because it refused the emphasis on timeless universality of medieval thought and grounded life in the "moment." This view normally led in his work to a stark differentiation of humanism from what came before. ${ }^{36}$ Funkenstein's model suggests that this distinction is typically overdrawn. Since the continuities between sacred and secular and medieval and modern are far more significant than the dominant view is often willing to allow, no persuasive account can omit them.

A main objective of Funkenstein's argument, then, is to suggest what transformation is wrought on the study of early modern historical thought when the revolution in historical methods is not kept artificially isolated and insulated from the study of the transformations of historical consciousness more broadly, so that the "subjective" side of history that underwent a revolution in the early modern period always has to be considered together with the "objective." According to Funkenstein, both kinds of historicism have theological origins. For in Hegel's words "It is an internal vital principle common to both that produces them simultaneously."

\section{From Modern Separation to Modernist Crisis}

Funkenstein's main achievement is to have insisted on the connection between historical scheme and method, a connection for which he argued begin-

${ }^{36}$ See esp. Pocock, Politics, Language, and Time: Essays on Political Thought and History (New York, 1971), 80-85, for an entirely unguarded argument to this effect and The Machiavellian Moment: Florentine Political Thought and the Atlantic Republican Tradition (Princeton, 1975), Part I. On this period, Funkenstein's contribution is far more in the spirit of Adelbert Klempt's Die Säkularisierung der universalhistorischen Auffassung: zum Wandel des Geschichtsdenkens im 16. und 17. Jahrhundert (Göttingen, 1960), a work he knew, than the restrictedly secular Anglo-American scholarship he hoped to supplement. Ironically, Butterfield, the teacher in whose thought Pocock's work in this area is rooted, showed himself far more aware of the pioneering German-language discussion on the topic and, as a committed Christian thinker, may have been more open to the notion of a theological background to modern historiography. Butterfield's Man on His Past is littered with references to the Wilhelmine and Weimar discussion, for example, Hans Proesler, Das Problem einer Entwicklungsgeschichte des historischen Sinnes (Berlin, 1920). 
ning in his dissertation. If Funkenstein's approach is correct, the study of the development of historical consciousness commits one to a far more generaland admittedly more elusive - inquiry than the study of the progress of historical methodology would by itself. Nonetheless, if the hypothesis that historical methodology presupposes historical consciousness proves sustainable, then it turns out to be a necessary inquiry. For then it does not necessarily follow that the best place to look for the conditions for revolutions in historical thought is in the books of history or the practices of historians alone. For the methodological self-awareness of the history books and writers of a one period may depend on the historical consciousness nurtured in quite unrelated sources before.

Yet Funkenstein left open the question how the connection between the two historicisms came to be severed, and their prior relationship obscured, in the modern historian's consciousness. It is on this point that I would like to argue for a tension and a gap in Funkenstein's account. At some point, that account implies, the substantive and methodological versions of historicism reached a fateful point of separation. The "increased sense of the actual historical interdependence of institutions and the events within a period" initially originated out of "the evolutionary sense of an almost necessary sequence of periods. ${ }^{137}$ But in a reversal that shattered their original interdependence, these two insights subsequently became detached from one another. Strangely, Funkenstein did not explain how the historical sense became able to operate independently of the theological, eschatological framework which originally helped make it a possibility.

The existence and importance of this gap comes to seem more obvious as soon as one examines Funkenstein's writings more closely. For even as he consistently implied the original interdependence of the two kinds of historicism, he just as consistently separated his attempts to historicize them. The separation is especially clear in the various accounts Funkenstein gave of Maimonides, who figures in some places as a progenitor of dialectical materialism in his view of a necessaritarian and compulsive sequence of stages in history but appears in others as a precursor of the historical school in his view of the autonomy of discrete moments in time as meaningful wholes..$^{38}$ But it turns out that Funkenstein's explanatory separation of the two kinds of historicism from one another pervades his work. It seems that Funkenstein adopted compositionally the very distinction between the two historicisms that he denied conceptually.

It is possible that Funkenstein made the choice to separate the two historicisms simply in the interests of clear explanation, but there exists an alternative

\footnotetext{
${ }^{37}$ Funkenstein, Theology, 268.

${ }^{38}$ Cf. Funkenstein, Perceptions, 141-44 and 145-47.
} 
possibility, which is that he did not take seriously enough the conceptual immiscibility of the proto-teleological and the proto-historicist approaches to the past even when they were most unified. How is it, when they enjoyed an original fraternity, that the two historicisms could have later become such deadly opposites? The ultimate viability of Funkenstein's account, then, would turn on the availability of a plausible story of how the harmonious partnership became a hostile split. Why and how did the breakdown occur? Did it have to happen? Could it have been avoided?

These questions may not have seemed so pressing in the years that Funkenstein's project took root, but from the present standpoint, it may well seem like the origins of the catastrophic dissolution of the historicisms in the nineteenth century demand more attention. In his history of history Funkenstein aimed to historicize the unity of the two historicisms in Hegel's thought; but he did not effectively acknowledge — much less historically explain — the breakup of this unity, the "crisis of historicism" that Friedrich Nietzsche predicted and that soon occurred, and the alternative ways philosophers and philosophicallyminded historians have since proposed to respond to this crisis down to the present day. ${ }^{39}$ Funkenstein focused on a moment of reconciliation in taking Hegel as the endpoint of his story. In light of the agony of dissolution that ensued the history of history may well deserve a more tragic rendition than Funkenstein could give it by leaving the last acts out.

It is worthwhile to note, moreover, that Funkenstein's omission of a plausible story of the separation appears to leave his argument for the continuity of historical writing and historical consciousness with an important gap. The argument that the story of historical practice presupposes his own story of "historical consciousness" provided the crux of the well-known controversy which Funkenstein initiated against Yerushalmi. Even if the Jews did not write history, Funkenstein claimed, it by no means implied that they lacked historical awareness. Funkenstein claimed that his usage of "historical consciousness" as a "mediating category" between professional history and collective memory made the novelty of nineteenth-century Jewish historicism far less emphatic and unprecedented than Yerushalmi had supposed. It is not the worth of historical consciousness as a "mediating category" between history and memory that Funkenstein's omission leaves fragile; instead, the gap may undermine Funkenstein's attempt to offer the existence of that category by itself as evidence that the nature of historical consciousness did not change fundamentally

${ }^{39}$ See Bambach, Heidegger, Dilthey, and the Crisis of Historicism for a clear study of Martin Heidegger's attempt to overcome the relativistic crisis of values that followed from the German historical school. See also Barash, Martin Heidegger and the Problem of Historical Meaning (Dordrecht, 1988). Inadequate is Funkenstein's occasional suggestion that his argument explained the emergence of "universal hermeneutics," a philosophy that developed as a result of the crisis of historicism and its thorough regrounding in the work of Heidegger and Hans-Georg Gadamer. 
in the modern period. Differently put, Funkenstein's argument against Yerushalmi allowed a methodological distinction to accomplish too much substantive work, since the fact that history and memory are two forms of a more generalized historical consciousness by no means alters the fact that the distance between them became great enough for this deeper unity to be obscured in modern times. If it is with a prestigious, autonomous, and secular historicism that modernizing Jews came to affiliate, then knowing the distance of that outlook from more traditional forms of historical consciousness and how the distance became so great become the truly crucial problems, ones which Funkenstein did not adequately solve.

These considerations, to conclude, imply that Funkenstein's case-about the origins of modern historical reasoning as well as about the affiliation of Jews with that project-could become fully convincing only if he could explain not just the original unity that once characterized methodological and substantive historicism but their breakdown too, the uprooting of profane historical practice from the nourishing soil of sacralized historical expectation. ${ }^{40} \mathrm{I}$ believe the attachments between the two may have lingered and that in many milieux methodological historicism may have maintained a productive communion with teleological historicism through much of the nineteenth century. It is not so much that the slow pace of secularization allowed the persistence of archaic forms of knowledge; in secular guise, this communion gave the social theories of Hegel and Marx their extraordinary power-their inspired ability, never achieved before and rarely repeated since, to combine an interest in explanation of the past with a commitment to a vision of the future. The early modern period may have seen the beginnings of the breakdown of unity; but it required late modernity for it to be finally and fatefully completed.

At a memorial service Funkenstein's student David Biale labeled his teacher "the last German-Jewish philosopher." ${ }^{41}$ Whatever the justice of this title, it is certainly true that so far as the history of history is concerned Funkenstein's approach differed substantially from that current in the Anglo-American world today. It cast the problem of early modern history at a far more general, philosophical, even metaphysical level than that of simple methodological innovation - and therefore, perhaps, in a mode redolent of some German scholarship of the golden age.

When understood in relationship to contemporary scholarship, however, Funkenstein's work represents not only a counterpoint but also a challenge.

${ }^{40}$ See Funkenstein, "Collective Memory and Historical Consciousness," History \& Memory, 1 (1989), 5-26, and Perceptions, chap. 1. Cf. David N. Myers, "Remembering Zakhor: A Supercommentary," History \& Memory, 4 (1992), 129-48 along with Funkenstein's short reply.

${ }^{41}$ David Biale, "The Last German-Jewish Philosopher," in Biale et al., Amos Funkenstein: A Celebration (Berkeley, 1996), rpt. as "The Last German-Jewish Philosopher: Notes towards an Intellectual Biography of Amos Funkenstein,” Jewish Social Studies, n.s., 6 (1999), 1-5. 
The most important element of his challenge would appear to be the thesis that the rise of modern historical methods has to be studied together with the rise of the modern historical consciousness more generally - that the rise of historicism as a methodological principle has to be understood in part as "fallout" of the transformation of historicism as substantive worldview. For to cite Hegel's words again, "It is an internal vital principle common to both that produces them simultaneously."

The major significance of early modern European developments, if it is possible to make Funkenstein's thesis persuasive, is therefore not the invention of a new methodological outlook for historical inquiry but rather the separation of this outlook from a much older substantive framework rooted in theological premises. But this framework did not die either, for it became secularized into the great modern philosophies of history of the nineteenth century.

Even after Funkenstein's pioneering work the breakdown between the two kinds of historicism remains ill-understood. How the separation happened is a critical historical question Funkenstein left inadequately answered, with substantial implications for his theory of the relationship of historical practice to historical consciousness in the contemporary world.

Historicism cannot remain immune from itself. Professional historians sometimes are willing to accept the insight that the historical method itself has a history, that the way they presently approach the past implies not the existence of an exclusive and necessary organon but instead the provisional supremacy of one method among a plurality of diverse alternatives. Yet they rarely acknowledge so explicitly what this fact suggests, which is that the historical method may also therefore have a plurality of alternative futures. The modern historian, operating after the fateful distinction between knowledge about the past and hopes about the future, often defends the purity of historical investigation from the contamination of normative commitment. But in light of Funkenstein's recovery of the original dependence of modern historical thought as a method on a sense of the ultimate meaning and purpose of history as a process, this typical outlook seems contingent (and perhaps even confused).

Habitually mute on the contemporary implications raised by his work, Funkenstein left open the question whether and how to reunite two approaches to the past that, like long-lost brothers estranged from one another through the secularizations of their maturity, have forgotten the interdependence of their theological origins. Though fatefully separated later, these eventual foes were born together: this message appears to be the essential contribution of Funkenstein's career-long inquiry into history.

Columbia University. 